\title{
Regulation of 11ß-hydroxysteroid dehydrogenase type 1 in primary cultures of rat and human hepatocytes
}

\author{
M L Ricketts, K J Shoesmith ${ }^{1}$, M Hewison, A Strain ${ }^{1}$, M C Eggo \\ and $\mathbf{P}$ M Stewart
}

Department of Medicine and ${ }^{1}$ Liver Research Laboratories, University of Birmingham, Queen Elizabeth Hospital, Edgbaston, Birmingham B15 2TH, UK (Requests for offprints should be addressed to P M Stewart, Department of Medicine, Queen Elizabeth Hospital, Edgbaston, Birmingham B15 2TH, UK)

\begin{abstract}
Two isozymes of the enzyme $11 \beta$-hydroxysteroid dehydrogenase (11 $\beta-\mathrm{HSD})$ are responsible for the interconversion of the active glucocorticoid, cortisol in man, (corticosterone in the rodent), to the inactive 11-keto metabolite, cortisone (11-dehydrocorticosterone). We have examined the regulation of type $111 \beta-\mathrm{HSD}$ $(11 \beta-H S D 1)$ using primary cultures of rat and human hepatocytes, both of which express only $11 \beta-H S D 1$. Only 11 oxo-reductase activity could be demonstrated in cultured hepatocytes (apparent $K_{\mathrm{m}}$ for cortisone $382 \pm 43 \mathrm{nM}$ in human hepatocytes, apparent $K_{\mathrm{m}}$ for 11-dehydrocorticosterone $14.6 \pm 1.5 \mu \mathrm{M}$ in rat hepatocytes). There exists a marked discrepancy between $11 \beta-$ HSD oxo-reductase activity and $11 \beta-H S D 1$ mRNA levels in cultured human hepatocytes and human liver. Thus oxo-reductase specific activity is much higher in the cultured hepatocytes $(7 \cdot 2 \pm 0 \cdot 01 \mathrm{nmoles}$ cortisol $/ \mathrm{mg} / \mathrm{h}$ vs $0.89 \pm 0.06$ for whole liver homogenates) whilst the converse is true for steady state $11 \beta-\mathrm{HSD} 1 \mathrm{mRNA}$ levels $(0 \cdot 78 \pm 0.02$ vs $1.94 \pm 0.07$ in whole liver, $11 \beta-H S D 1 /$ $18 \mathrm{~S}$ expressed as arbitrary units).

Carbenoxolone has a significant inhibitory effect on 11 oxo-reductase activity in both rat and human hepato-

cytes. However, there is clear species-specific regulation of 11 oxo-reductase activity by thyroid hormone (tri-iodothyronine $\left(\mathrm{T}_{3}\right)$ ), which increases 11 oxo-reductase activity in rat hepatocytes but has no effect on activity in human hepatocytes, and progesterone which inhibits activity in human hepatocytes, but has no effect on activity in rat hepatocytes. Neither $\mathrm{T}_{3}$ nor progesterone altered $11 \beta-H S D 1$ mRNA levels. A series of growth factors (hepatocyte growth factor, epidermal growth factor, basic fibroblast growth factor, transforming growth factor $\beta_{1}$ ) were without effect on 11 oxo-reductase activity in cultured rat hepatocytes.

In contrast to homogenates of human liver, cultured hepatocytes express only $11 \beta$-HSD oxo-reductase activity. This is inhibited by carbenoxolone and shows speciesspecific regulation by $\mathrm{T}_{3}$ and progesterone. Growth factors do not appear to regulate activity or expression of $11 \beta$ HSD1. The discrepant enzyme activity data and $11 \beta-$ HSD1 mRNA expression in hepatocytes and whole liver could reflect unstable 11 $\beta$-HSD1 oxo-reductase activity or, alternatively, an additional $11 \beta-\mathrm{HSD}$ oxo-reductase isoform in cultured hepatocytes.

Journal of Endocrinology (1998) 156, 159-168
\end{abstract}

\section{Introduction}

$11 \beta$-Hydroxysteroid dehydrogenase (11 $\beta$-HSD) (EC. 1.1.1.146) is the enzyme complex responsible for the interconversion of the active glucocorticoids cortisol (Kendalls' compound $\mathrm{F}$ ) in man and corticosterone (compound $\mathrm{B}$ ) in the rodent, to their hormonally inactive 11-keto metabolites, cortisone (compound $\mathrm{E}$ ) and 11-dehydrocorticosterone (compound A) respectively (Monder \& Shackleton 1984). Two isozymes of $11 \beta-H S D$ have been cloned and characterised. Type $111 \beta-H S D$ was originally purified from rat liver microsomes (Lakshmi \& Monder 1988), and subsequently both rat and human complementary DNAs have been isolated (Agarwal et al. 1989, Tannin et al. 1991). Human type $111 \beta-H S D$ (11 $\beta-H S D 1)$ is a revers- ible NADP/NADPH-dependent isozyme with a $K_{\mathrm{m}}$ for cortisol of $2 \cdot 1 \mu \mathrm{M}$ and a $K_{\mathrm{m}}$ for cortisone of $0.3 \mu \mathrm{M}$, suggesting that in vivo this isozyme behaves predominantly as an oxo-reductase, whilst type $211 \beta-H S D$ (11 $\beta-H S D 2)$ is a high affinity uni-directional dehydrogenase with a $K_{\mathrm{m}}$ for cortisol in man of $50 \mathrm{nM}$ (Brown et al. 1993, Stewart et al. 1994). Type $211 \beta-H S D$ cDNA has also been isolated from many species including human (Albiston et al. 1994) and rat (Zhou et al. 1995).

Recent studies have shown that mutations in the gene encoding $11 \beta-\mathrm{HSD} 2$ account for a unique form of inherited human hypertension, the syndrome of apparent mineralocorticoid excess (Mune et al. 1995, Wilson et al. 1995, Stewart et al. 1996). It is this type 2 isozyme of $11 \beta-H S D$ which dictates specificity upon the 
mineralocorticoid receptor (MR) (Edwards et al. 1988). In contrast, the type $111 \beta-\mathrm{HSD}$ isozyme is predominantly localized to glucocorticoid target tissues: liver, lung, gonad, and central nervous system (Whorwood et al. 1995). At these sites, modulation of $11 \beta-H S D 1$ activity has been shown to regulate glucocorticoid hormone action (Whorwood et al. 1993a, Monder et al. 1994, Jamieson et al. 1995, Rajan et al. 1996).

Previous studies which addressed the regulation of $11 \beta-H S D$ were largely carried out prior to the cloning of the second isozyme. In vitro studies evaluating the effects of thyroid hormone (tri-iodothyronine $\left(\mathrm{T}_{3}\right)$ ) (Whorwood et al. 1993b), sex steroids (Low et al. 1993) and glycyrrhetinic acid, the active component of liquorice (Monder et al. 1989) were carried out on rodent tissues or established cell lines, which are now known to express both isozymes of $11 \beta$-HSD. A classic example of this is the rodent kidney which, in contrast to human kidney expresses abundant amounts of both $11 \beta$-HSD types 1 and 2 . In addition, clinical studies evaluating urinary cortisol metabolites have invariably been unable to dissect out alterations in the type 1 (liver) or type 2 (renal) enzyme (Stewart et al. 1993, Rodin et al. 1994).

$11 \beta-H S D 1$ is now established as a crucial pre-receptor signalling pathway for the glucocorticoid receptor and the regulation of this isozyme at a tissue level will have ramifications for glucocorticoid hormone action. With this in mind we have established an in vitro system to analyse further the regulation of $11 \beta-H S D 1$.

\section{Materials and Methods}

\section{Isolation and culture of hepatocytes}

Primary rat hepatocytes were obtained from male Wistar rats weighing approximately $225 \mathrm{~g}$. Normal human liver tissue, excess to surgical transplant requirements was obtained from the segmental graft liver programme, Queen Elizabeth Hospital, Birmingham, under guidelines approved by the local Hospital Ethical Committee. All patients were male and aged between 7 and 51 years old. Hepatocytes were isolated and maintained aseptically at $4{ }^{\circ} \mathrm{C}$ in preservation fluid (either University of Wisconsin or Euro-Collins) (Ismail et al. 1991). Cells were normally isolated 12 to $24 \mathrm{~h}$ after removal of the liver from the donor. Both rat and human hepatocytes were isolated via two-step collagenase perfusion (modification of the method developed by Seglen) (Seglen 1976, Strain et al. 1991). Viability of cells was assessed by trypan blue exclusion and was $>85 \%$. Percoll gradients were used in some preparations of human hepatocytes to improve cell viability.

Cells were plated at a density of $3 \times 10^{5} / \mathrm{ml}$ on rat-tail collagen-coated dishes $(35 \mathrm{~mm})$ in $2 \mathrm{ml}$ plating medium (Dulbecco's modified essential medium (DMEM) and 10\% newborn calf serum (NCS) (Gibco, Paisley, Scotland)).
After approximately 1-2 h, attached cells were washed in phosphate-buffered saline (PBS) and refed with serumfree Williams E medium (Gibco) supplemented with $0.4 \mathrm{mM}$ ornithine, $100 \mathrm{nM}$ insulin, $100 \mathrm{U} / \mathrm{ml}$ penicillin and $100 \mu \mathrm{g} / \mathrm{ml}$ streptomycin. Cultures were incubated for $72 \mathrm{~h}$ at $37^{\circ} \mathrm{C}$ in $5 \% \mathrm{CO}_{2} / 95 \%$ air and media were changed daily. Under these conditions rat hepatocytes could be cultured for up to a maximum of 7 days before they detached, and human hepatocytes could be cultured for 10-14 days. However, experiments were always performed 48-72 h after isolation, when the cells were at the peak of S-phase (Ismail et al. 1991). Each experiment was repeated with hepatocytes from three separate preparations, and in each case in triplicate.

\section{Enzymatic analysis}

Determination of $K_{\mathrm{m}}$ for 11 oxo-reductase in rat and human hepatocytes Primary hepatocytes were incubated for $48 \mathrm{~h}$ in serum-free Williams $\mathrm{E}$ medium, after which the cells were incubated with various concentrations of substrate ranging from $50 \mathrm{nM}-20 \mu \mathrm{M} 11$ dehydrocorticosterone (with $\left.{ }^{3} \mathrm{H}\right] 11$-dehydrocorticosterone as tracer) for $10 \mathrm{~min}$. Similarly human hepatocytes were incubated with various concentrations of cortisone $\left(0 \cdot 01-2 \cdot 5 \mu \mathrm{M}\right.$, with $\left[{ }^{3} \mathrm{H}\right]$ cortisone as tracer). $\left[{ }^{3} \mathrm{H}\right] 11-$ Dehydrocorticosterone and $\left[{ }^{3} \mathrm{H}\right]$ cortisone were synthesized in-house as previously described (Shimojo et al. 1996).

The steroids were extracted using dichloromethane, and run on TLC plates to separate the two steroids using 8:92, ethanol:chloroform as the mobile phase. TLC plates were scanned on a Bioscan imaging detector for $10 \mathrm{~min}$ and the fractional conversion of 11-dehydrocorticosterone to corticosterone, or cortisone to cortisol was calculated.

Regulation studies Hepatocytes were pre-treated for 4 or $16 \mathrm{~h}$ with various factors, such as carbenoxolone, $\mathrm{T}_{3}$, progesterone, and growth factors (hepatocyte growth factor (HGF), epidermal growth factor (EGF) basic fibroblast growth factor (bFGF), transforming growth factor $\left.\beta_{1}\left(\mathrm{TGF} \beta_{1}\right)\right)$, followed by incubation with $1 \mu \mathrm{M}$ 11-dehydrocorticosterone for $15 \mathrm{~min}$ with $\left[{ }^{3} \mathrm{H}\right] 11$ dehydrocorticosterone as tracer (rat), or $0.5 \mu \mathrm{M}$ cortisone for $1 \mathrm{~h}$ with $\left[{ }^{3} \mathrm{H}\right]$ cortisone as tracer (human). At these substrate concentrations and time points product formation was linear, i.e. first order kinetics were maintained. The steroids were extracted as above, and the fractional conversion of 11-dehydrocorticosterone to corticosterone, or cortisone to cortisol was calculated. Dehydrogenase activity was assessed by incubating rat hepatocytes with concentrations of $0 \cdot 1,1$ and $10 \mu \mathrm{M}$ corticosterone with $\left[{ }^{3} \mathrm{H}\right]$ corticosterone as tracer, or human hepatocytes with $0 \cdot 1,1$ and $10 \mu \mathrm{M}$ cortisol with $\left[{ }^{3} \mathrm{H}\right]$ cortisol as tracer for varying time intervals between $5 \mathrm{~min}$ and $16 \mathrm{~h}$. No dehydrogenase activity was observed in either case. 
Enzyme activity studies in liver homogenates Normal human liver tissue was homogenized and $100 \mu \mathrm{g} / \mathrm{ml}$ protein were incubated in $100 \mathrm{mM}$ potassium phosphate buffer (pH 7.6), containing 200000 d.p.m. $\left[{ }^{3} \mathrm{H}\right]$ cortisol, $0 \cdot 5-2 \cdot 5 \mu \mathrm{M}$ cortisol, and $400 \mu \mathrm{M}$ NADP for $1 \mathrm{~h}$ at $37^{\circ} \mathrm{C}$ in a shaking water-bath $(n=3$, in triplicate).

Similarly, 11 oxo-reductase activity was assessed over a range of substrate concentrations $(0 \cdot 1-20 \mu \mathrm{M}$ cortisone, with $\left[{ }^{3} \mathrm{H}\right]$ cortisone as tracer), in the presence of $400 \mu \mathrm{M}$ $\mathrm{NADPH}$ for $1 \mathrm{~h}$. The steroids were extracted as above and run on TLC.

\section{Statistical analysis}

In each case experimental data are described as the mean \pm s.E.M. of three replicates of three different cultures. Data were compared using analysis of variance and Dunnet's post hoc tests as appropriate, with significance set at $P<0 \cdot 05$.

\section{$m R N A$ analysis}

Total RNA was isolated from rat and human hepatocytes using RNAzol B (AMS Biotechnology Ltd, Oxon, UK) and a single-step extraction method based on that of Chomczynski and Sacchi (1987). Northern blot analysis was performed as previously described (Whorwood et al. 1993a). Briefly, $20 \mu \mathrm{g}$ total RNA were electrophoresed in a $1.5 \%$ agarose $/ 15 \%$ formaldehyde gel containing ethidium bromide in $1 \times$ MOPS (morpholinopropanesulphonic acid buffer) (Sigma Chemical Company, Poole, Dorset, UK) at $100 \mathrm{~mA}$ for $4 \mathrm{~h}$. RNA was transferred onto a nylon (Hybond $\mathrm{N}^{+}$) membrane (Amersham International, Aylesbury, Bucks, UK) and U/V cross-linked (Hoefer Cross-Linker, San Francisco, CA, USA). 18S and 28 S ribosomal bands were visualised under UV light and marked on the membrane. For probe hybridizations $(11 \beta-$ HSD1 and 18S cDNAs), each membrane was prehybridized at $65{ }^{\circ} \mathrm{C}$ in hybridization buffer $(0.77 \mathrm{M}$ sodium phosphate, $5 \mathrm{mM}$ EDTA, 7\% sodium dodecyl sulphate (SDS), and $100 \mu \mathrm{g} / \mathrm{ml}$ denatured salmon sperm DNA, $\mathrm{pH}$ $7 \cdot 2$ ) followed by hybridization with the probes for $16 \mathrm{~h}$ at $65^{\circ} \mathrm{C}$. Membranes were washed in $2 \times$ SSC for $20 \mathrm{~min}$ at room temperature, followed by $2 \times \mathrm{SSC} / 1 \% \mathrm{SDS}$ at $65^{\circ} \mathrm{C}$ for $30 \mathrm{~min}$ and to a final stringency of $0.1 \times \mathrm{SSC}$ for $10 \mathrm{~min}$ at room temperature $(1 \times \mathrm{SSC}=150 \mathrm{mM}$ sodium chloride, $15 \mathrm{mM}$ trisodium citrate). All membranes were exposed to Dupont Cronex X-ray film with intensifying screens at $-70^{\circ} \mathrm{C}$ for between $2 \mathrm{~h}$ and 14 days. Before rehybridization with other probes, membranes were stripped of cDNA probes by washing with $1 \%$ SDS at $70{ }^{\circ} \mathrm{C}$ for $3 \mathrm{~h}$.

\section{Probes}

The cDNAs encoding rat liver type $111 \beta-H S D$ (1265 basepairs (bp)) (Agarwal et al. 1989), the human type 1
11ß-HSD (1230 bp) (Tannin et al. 1991) and a rat 18S ribosomal DNA (1070 bp) (Chan et al. 1984), were radiolabelled with $\left[{ }^{32} \mathrm{P}\right]$ deoxy-CTP $\quad(3000 \mathrm{Ci} / \mathrm{mmol}$; Amersham International) by oligonucleotide random priming of the excised cDNA fragment using a commercially available kit (Pharmacia, Uppsala, Sweden).

\section{Results}

Regulation studies used primary cultures of rat and human hepatocytes, both of which only convert the inactive metabolite cortisone in man, or 11-dehydrocorticosterone in the rodent, to the active form cortisol or corticosterone. In keeping with these enzyme activity results, reverse transcription (RT)-PCR studies (Whorwood et al. 1995) detected only type $111 \beta$-HSD expression in liver; type 2 $11 \beta-H S D$ was absent in liver and hepatocytes (data not shown).

Kinetic analysis of rat $11 \beta-H S D$ oxo-reductase activity revealed a low affinity enzyme. From LineweaverBurk plots we established the apparent $K_{\mathrm{m}}$ for 11dehydrocorticosterone in rat hepatocytes to be $14.6 \pm 1.5 \mu \mathrm{M}$ (mean \pm s.e., $n=3$ in triplicate), and $382 \pm 43 \mathrm{nM}$ for cortisone in human hepatocytes (Fig. 1).

Parallel Northern blot analyses and activity studies carried out on cultured human hepatocytes and whole human liver revealed discrepant results (Fig. 2). Specific activity (nmoles cortisol formed/mg protein/h) was much higher in cultured hepatocytes $(7 \cdot 2 \pm 0 \cdot 01)$ compared with whole liver homogenates $(0.89 \pm 0.06)$ whilst the converse was true for $11 \beta$-HSD1 mRNA expression $(11 \beta$-HSD1/18S, expressed as arbitrary units, $0 \cdot 78 \pm 0 \cdot 02$ for hepatocytes, $1.94 \pm 0.07$ for liver, $P<0.001)$.

Screening studies were performed on both rat and human hepatocytes. Table 1 shows the effects of various factors on rat and human hepatocyte 11 oxo-reductase activity. As shown in Table 2, a series of putative regulatory factors including $\mathrm{HGF}, \mathrm{bFGF}$ and $\mathrm{TGF} \beta_{1}$ were without effect on 11 oxo-reductase activity in rat hepatocytes. Initial experiments using relatively high doses of progesterone, $\mathrm{T}_{3}$ and carbenoxolone (CBX) indicated that progesterone inhibited activity in human hepatocytes but not in rat hepatocytes, whereas $T_{3}$ increased activity in rat, but not human hepatocytes. CBX significantly inhibited activity in both systems at $4 \mathrm{~h}$ pretreatment (Table 1 ).

The effects of $T_{3}$ and progesterone were further evaluated. There was an increase in $11 \beta-H S D 1$ oxo-reductase activity following pre-incubation with $\mathrm{T}_{3}\left(10^{-11}\right.$ $10^{-7} \mathrm{M}$ ) for $16 \mathrm{~h}$ in rat hepatocytes (Fig. 3a). In human hepatocytes there was a dose-dependent decrease in oxoreductase activity following incubation with progesterone for $16 \mathrm{~h}$. The maximal effective dose of progesterone in this regard was $10^{-6} \mathrm{M}$ (Fig. 4a). Despite these changes in enzyme activity no significant changes in rat $11 \beta$ HSD1 mRNA levels were observed following treatment 


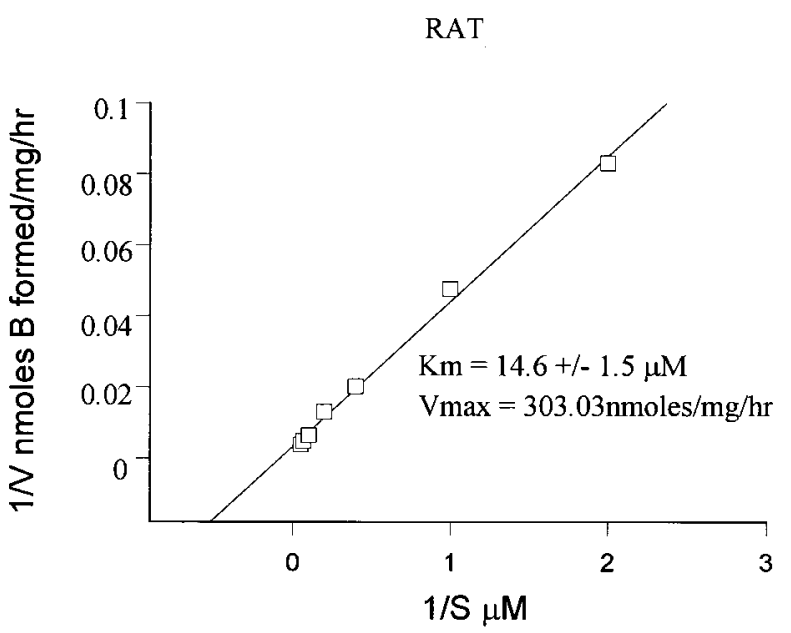

HUMAN

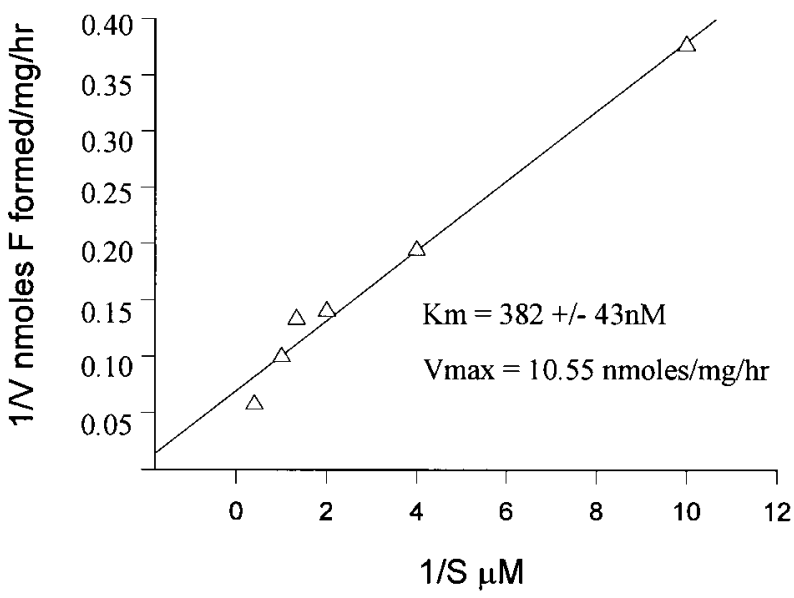

Figure 1 Lineweaver-Burk plots showing $1 / \mathrm{V}$ plotted against $1 / \mathrm{S}$ to establish the $K_{\mathrm{m}}$ and $\mathrm{V}_{\max }$ for 11 oxo-reductase in rat and human hepatocytes.

with thyroid hormone (Fig. 3b), and no significant changes were observed in human 11ß-HSD1 mRNA levels following treatment with progesterone (Fig. $4 b$ ).

Further analysis of the effects of CBX on the inhibition of 11 oxo-reductase activity in rat hepatocytes can be seen in Table 3. At both 4 and $16 \mathrm{~h}$ pre-treatment there was significant inhibition of activity, but with doses of CBX greater than $10^{-5} \mathrm{M}$. There was no change in type 1 $11 \beta-H S D$ mRNA levels (not shown). Similar results were observed with CBX on human hepatocytes following incubation for $4 \mathrm{~h}$ in the presence of $1 \mu \mathrm{M}$ cortisone (Table 3).

\section{Discussion}

Two kinetically distinct isozymes of $11 \beta-H S D$ catalyse the interconversion of hormonally active cortisol to inactive

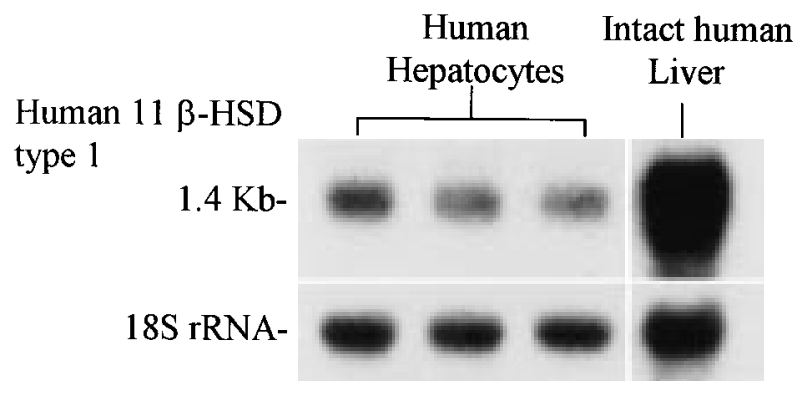

activity (nmoles/mg/hr)

Oxo-reductase : $\quad 7.20 \quad 0.89$

Dehydrogenase : $\quad 0 \quad 2.63$

Figure 2 Northern blot showing the expression of type 1 $11 \beta$-hydroxysteroid dehydrogenase mRNA in cultured human hepatocytes compared with whole human liver. Hybridization to $18 \mathrm{~S}$ rRNA is also shown as a control. The Table beneath the Northern blot shows the specific activities (expressed as nmoles $/ \mathrm{mg} / \mathrm{h}$ ) for both 11 oxo-reductase and dehydrogenase activity in cultured human hepatocytes and whole human liver.

cortisone (Monder \& Shackleton 1984, Tannin et al. 1991, Brown et al. 1993, Albiston et al. 1994, Stewart et al. 1994). The liver, or type 1 isozyme of $11 \beta$-HSD behaves predominantly as an oxo-reductase in vivo generating cortisol from cortisone. This evidence comes from several sources. First, cortisol/cortisone affinity studies carried out on the expressed human 11 $\beta$-HSD isozyme reveal a lower $K_{\mathrm{m}}$ for cortisone than cortisol (Stewart et al. 1994). Secondly, selective venous catheterisation studies indicate low cortisone but high cortisol concentrations within the hepatic vein (Walker et al. 1992), in keeping with the observation that cortisone, taken by mouth, is rapidly converted to cortisol, with little or no change in circulating cortisone concentrations in the peripheral plasma (Stewart et al. 1990). Finally, recent experiments similar to those conducted herein on cultured rat hepatocytes have indicated high amounts of 11 oxo-reductase activity, with little or no dehydrogenase activity in intact cells (Jamieson et al. 1995).

The liver is known to express high levels of glucocorticoid receptors. Glucocorticoid receptors have 10-40 times lower affinity for cortisol compared with mineralocorticoid receptors which are not very abundant in the liver, and hepatic $11 \beta-H S D$ is thought to be required to ensure adequate exposure of cortisol to these low affinity glucocorticoid receptors (Walker et al. 1995). Thus the presence of a $11 \beta-H S D$ oxo-reductase ensures conversion of cortisone to cortisol and, therefore, adequate exposure to the glucocorticoid receptor. Primary cultures of hepatocytes are an excellent model to use to study the regulation of this enzyme (Jamieson et al. 1995) as they 
Table 1 Effect of various factors on 11 oxo-reductase activity in rat and human hepatocytes after 4 and $16 \mathrm{~h}$ incubation. Results are means \pm S.E. $(n=4)$ and are expressed as percentage conversion of either A to B (11-dehydrocorticosterone to corticosterone) (rat hepatocytes) or $\mathrm{E}$ to $\mathrm{F}$ (cortisone to cortisol) (human hepatocytes) relative to control

Percentage conversion A to B

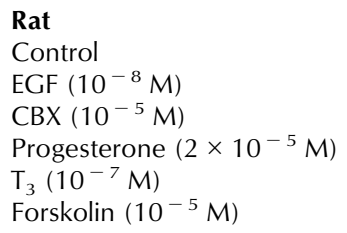

\section{Human}

Control

CBX $\left(10^{-5} \mathrm{M}\right)$

Progesterone $\left(2 \times 10^{-5} \mathrm{M}\right)$

$\mathrm{T}_{3}\left(10^{-7} \mathrm{M}\right)$

Forskolin $\left(10^{-5} \mathrm{M}\right)$

${ }^{* *} P<0 \cdot 01$ compared with control.
EGF $\left(10^{-8} \mathrm{M}\right)$

\begin{tabular}{|c|c|}
\hline $4 \mathrm{~h}$ & $16 \mathrm{~h}$ \\
\hline $\begin{aligned} 100 \cdot 00 & \pm 5 \cdot 59 \\
101 \cdot 56 & \pm 1 \cdot 85 \\
57 \cdot 14 & \pm 12 \cdot 45^{\star *} \\
101 \cdot 19 & \pm 1 \cdot 50 \\
110 \cdot 69 & \pm 4 \cdot 48 \\
106 \cdot 33 & \pm 0 \cdot 77\end{aligned}$ & $\begin{aligned} 100 \cdot 00 & \pm 4 \cdot 54 \\
95 \cdot 83 & \pm 4 \cdot 93 \\
82 \cdot 69 & \pm 6 \cdot 52 \\
105 \cdot 34 & \pm 4 \cdot 48 \\
127 \cdot 99 & \pm 3 \cdot 29^{* *} \\
106 \cdot 37 & \pm 0 \cdot 26\end{aligned}$ \\
\hline \multicolumn{2}{|c|}{ Percentage conversion $E$ to $F$} \\
\hline $4 \mathrm{~h}$ & $16 \mathrm{~h}$ \\
\hline $\begin{aligned} 100 \cdot 00 & \pm 3 \cdot 92 \\
103 \cdot 34 & \pm 3 \cdot 91 \\
64 \cdot 17 & \pm 1 \cdot 01^{* *} \\
27 \cdot 39 & \pm 1 \cdot 18^{* *} \\
94 \cdot 06 & \pm 2 \cdot 57 \\
107 \cdot 45 & \pm 0 \cdot 59\end{aligned}$ & $\begin{aligned} 100 \cdot 00 & \pm 9 \cdot 13 \\
105 \cdot 86 & \pm 2 \cdot 60 \\
70 \cdot 69 & \pm 1 \cdot 21 \\
36 \cdot 02 & \pm 1 \cdot 72^{* *} \\
109 \cdot 95 & \pm 1 \cdot 18 \\
107 \cdot 13 & \pm 2 \cdot 24\end{aligned}$ \\
\hline
\end{tabular}

Table 2 The effect of $\operatorname{HGF}(1,10,50$ and $100 \mathrm{ng} / \mathrm{ml})$, bFGF (10 and $40 \mathrm{ng} / \mathrm{ml})$ and TGF $\beta_{1}$ ( 1 and $10 \mathrm{ng} / \mathrm{ml}$ ) on 11 oxo-reductase activity in cultured rat hepatocytes. Results are means \pm S.E. $(n=3)$ and are expressed as percentage conversion of A to B

(11-dehydrocorticosterone to corticosterone) relative to control

\section{Percentage conversion A to B}

\section{Growth factor}

Control

HGF

bFGF

TGF $\beta_{1}$

\section{Dose}

$\begin{array}{lc}1 \mathrm{ng} / \mathrm{ml} & 113 \cdot 60 \pm 3 \cdot 48 \\ 10 \mathrm{ng} / \mathrm{ml} & 116 \cdot 76 \pm 2 \cdot 91 \\ 50 \mathrm{ng} / \mathrm{ml} & 105 \cdot 94 \pm 4 \cdot 02 \\ 100 \mathrm{ng} / \mathrm{ml} & 102 \cdot 16 \pm 5 \cdot 92 \\ & \\ 10 \mathrm{ng} / \mathrm{ml} & 108 \cdot 15 \pm 1 \cdot 88 \\ 40 \mathrm{ng} / \mathrm{ml} & 107 \cdot 23 \pm 2 \cdot 04 \\ & \\ 1 \mathrm{ng} / \mathrm{ml} & 101 \cdot 05 \pm 3 \cdot 00 \\ 10 \mathrm{ng} / \mathrm{ml} & 103 \cdot 97 \pm 3.04\end{array}$

$P>0.05$ in all experiments.

represent a pure source of type $111 \beta-H S D$ as determined by RT-PCR studies. No type $211 \beta-H S D$ is present within these cells. In contrast to the earlier studies of Jamieson et al. (1995), our experimental model involved both rat and human hepatocytes cultured on collagencoated dishes in serum-free conditions. Experiments were performed within $72 \mathrm{~h}$ after cell isolation, which precludes overgrowth of other cell types and increases the likelihood that the hepatocytes themselves would deviate less radically from their physiological state within the animal than in longer-term cultures, where a progression of adaptive changes to in vitro conditions could be a possibility (Bissell \& Guzelian 1980).

11 Oxo-reductase activity in rat hepatocytes was unaffected by cAMP (forskolin) and the growth factors HGF, $\mathrm{bFGF}$ and TGF $\beta_{1}$. cAMP regulates related hydroxysteroid dehydrogenases including $3 \beta$-HSD, $17 \beta-$ HSD (Tremblay $\&$ Beaudoin 1993) and the type 2 isozyme of $11 \beta-H S D$ (placenta but not kidney) (Pasquarette et al. 1996). Both HGF and TGF $\beta_{1}$ have profound effects on 

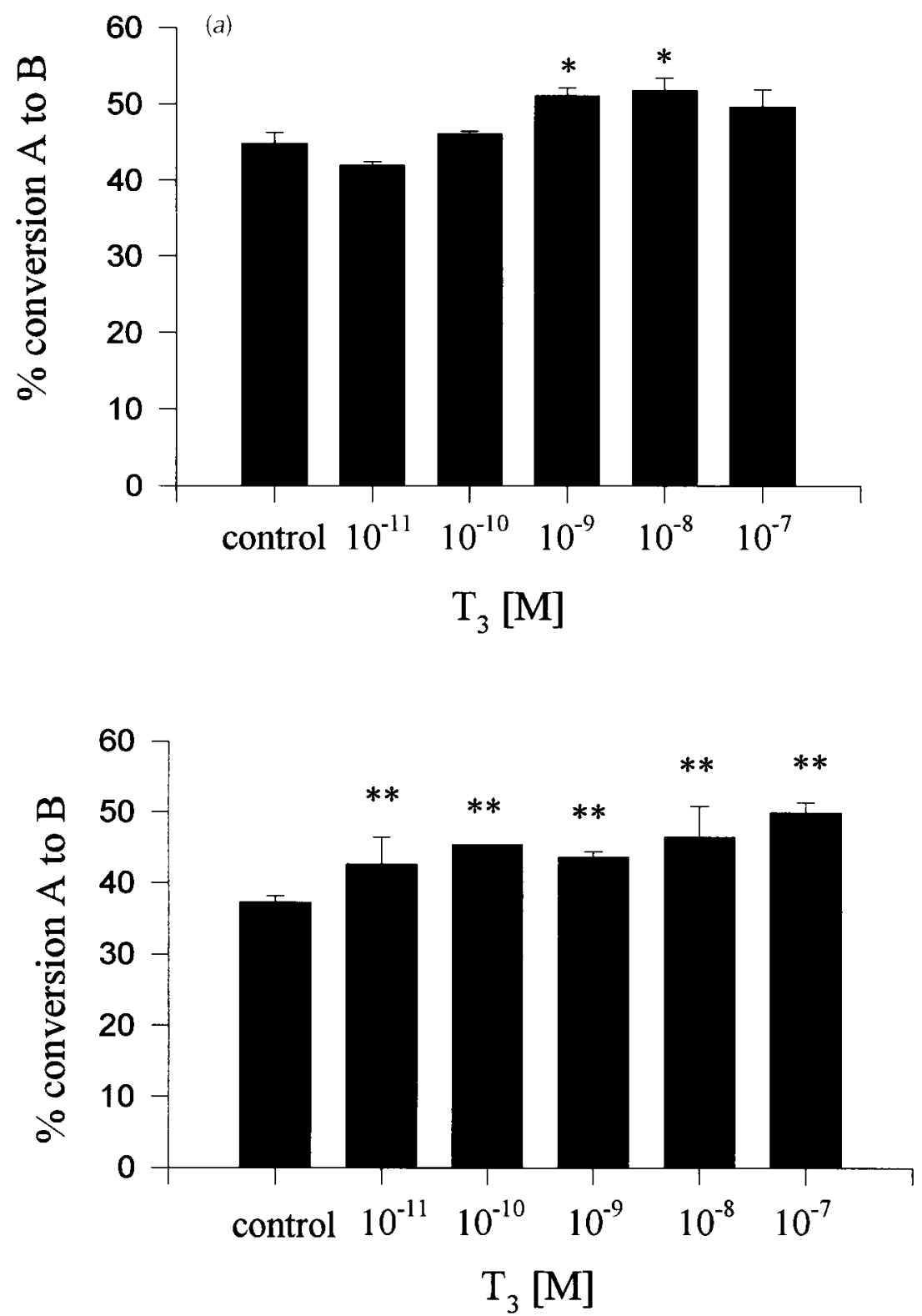

(b)

[T3] M

Rat $11 \beta$-HSD type 1

$1.4 \mathrm{~Kb}-$

$18 \mathrm{~S}$ rRNA- 
hepatocyte growth and DNA synthesis (Braun et al. 1988, Strain et al. 1991), but in our rat hepatocyte culture system had no effect on 11 $\beta-$ HSD1 activity or expression and, by inference, no effect on glucocorticoid availability in vivo.

Previous studies have shown that CBX and glycyrrhetinic acid (GE) exert an inhibitory effect on 11 $\beta-H S D$ (Monder et al. 1989, Stewart et al. 1990, Whorwood et al. 1993a) but this is the first time that CBX has been shown to inhibit hepatic 11 oxo-reductase in vitro. High doses of CBX $\left(10^{-4} \mathrm{M}\right)$ were required to inhibit $11 \beta-\mathrm{HSD} 1$ oxo-reductase activity, in keeping with our earlier studies on the expressed 11ß-HSD1 isozyme (Bujalska et al. 1997). Despite inhibition of activity, 11 $\beta-H S D 1$ messenger RNA levels did not change, suggesting competitive inhibition. We have previously demonstrated that the related compounds glycyrrhizic and glycyrrhetinic acids do inhibit $11 \beta-\mathrm{HSD} 1 \mathrm{mRNA}$ levels in vivo and in vitro (Monder et al. 1989, Whorwood et al. 1993a), but after culture for $24 \mathrm{~h}$. There is no doubt that these liquorice derivatives are competitive inhibitors of the $11 \beta-H S D$ proteins and more prolonged exposure of the hepatocytes to CBX may have resulted in an inhibition of mRNA levels. Clinically, the inhibition of hepatic 11 $\beta$-HSD1 activity may explain why liquorice and its derivatives do not cause such a marked increase in the ratio of urinary cortisol/cortisone metabolites as seen in apparent mineralocorticoid excess (Stewart et al. 1990), the hypertensive condition caused by defective $11 \beta-\mathrm{HSD} 2$ activity. CBX has also been shown to increase hepatic insulin sensitivity, consistent with a fall in intra-hepatic glucocorticoid activation following inhibition of hepatic 11 oxo-reductase activity (Walker et al. 1995).

The experiments with $\mathrm{T}_{3}$ revealed a discrepant action on rat and human 11ß-HSD1, with an increase in oxo-reductase activity in rat hepatocytes, but not in human hepatocytes. Previous experiments with $\mathrm{T}_{3}$ were carried out prior to the knowledge of two discrete $11 \beta-H S D$ isozymes, and invariably studied only dehydrogenase activity. $11 \beta-H S D$ dehydrogenase activity was decreased in rats treated with thyroid hormone in vivo, but $\mathrm{T}_{3}$ had no effect on activity when added directly to homogenates in vitro (Koerner \& Hellman 1964, Whorwood et al. 1993b), suggesting an indirect effect. In man, there is compelling data from urinary steroid measurements and plasma cortisol half-life studies that $\mathrm{T}_{3}$ does alter 11 $\beta$-HSD1 activity (increased reductase activity) (Hellman et al. 1961, Zumoff et al. 1983), but we could not demonstrate this in our culture system. It is possible that a more prolonged exposure to $T_{3}$ is required in man, or that the effect of $\mathrm{T}_{3}$ is dependent upon secondary 'circulating' factors, as suggested in earlier publications (Whorwood et al. 1993a).

This species-specific regulation was also true for progesterone which inhibited human, but not rat 11 oxo-reductase activity. The minimal effective dose was in the micromolar range, a concentration which is clearly seen in stimulated human ovarian cycles, and compares favourably with doses used to evaluate $11 \beta-H S D$ regulation in human granulosa-lutein cells (Clarke et al. 1995). Progesterone is known to act as a glucocorticoid agonist, and it is possible that its inhibition of $11 \beta-\mathrm{HSD}$ oxo-reductase activity within hepatocytes actually prevents tissue glucocorticoid excess at times of high circulating concentrations. The explanation for the differences between rat and human systems, however, is unclear. It is also of interest to note that progesterone markedly induces expression of both the type 1 and type 2 isozymes of 17 $\beta-\mathrm{HSD}$ (Casey et al. 1994, Poutanen et al. 1995), one of the closest 'relatives' to 11 $\beta-\mathrm{HSD}$ in the short-chain alcohol dehydrogenase superfamily (Krozowski 1992).

$11 \beta-H S D 1$ mRNA levels were detectable in RNA from hepatocyte cultures, though there is reduced expression compared with whole human liver. The specific activity data showed abundant oxo-reductase activity within cultured hepatocytes, but no dehydrogenase activity was detectable. This is very much in contrast to activity in liver homogenates where there is much less oxo-reductase activity, and more dehydrogenase activity, but it does emphasise the point made by others that in an intact cell system 11ß-HSD1 is a reductase (Jamieson et al. 1995). In homogenates in vitro the enzyme can be driven in either direction with addition of co-factor, but for physiological regulation studies we would argue that intact cell systems should be used.

Notwithstanding this there appeared to be a discrepancy between the levels of 11 oxo-reductase activity and $11 \beta$-HSD1 mRNA levels in cultured hepatocytes compared with whole liver. Thus, despite impressive oxoreductase activity in cultured hepatocytes, the converse was seen for $11 \beta-H S D 1$ mRNA levels. One explanation for this discrepancy could be that hepatocytes in culture no longer perform de novo synthesis of $11 \beta$-HSD1 and the $\mathrm{mRNA}$ and/or protein present is that which is present when the hepatocytes were first isolated. This seems unlikely as we can demonstrate high levels of oxoreductase activity for up to 14 days in primary culture. A further explanation is that the $11 \beta$-HSD1 oxo-reductase activity is highly unstable in homogenates in vitro. One

Figure 3 (a) Effects of $10^{-7}-10^{-11} \mathrm{M} \mathrm{T}_{3}$ on 11 oxo-reductase activity in rat hepatocytes. The upper panel represents pre-treatment for $4 \mathrm{~h}$, and the lower panel represents pre-treatment for $16 \mathrm{~h}$. Results are expressed as percentage conversion of A to B (11-dehydrocorticosterone to corticosterone). ${ }^{*} P<0 \cdot 05,{ }^{*} P<<0 \cdot 01$ compared with control. (b) Northern blot showing the expression of type 1 $11 \beta$-hydroxysteroid dehydrogenase mRNA in cultured rat hepatocytes treated with various doses of $\mathrm{T}_{3}\left(10^{-7}-10^{-11} \mathrm{M}\right)$. Hybridization to $18 \mathrm{~S}$ rRNA is also shown as a control. 


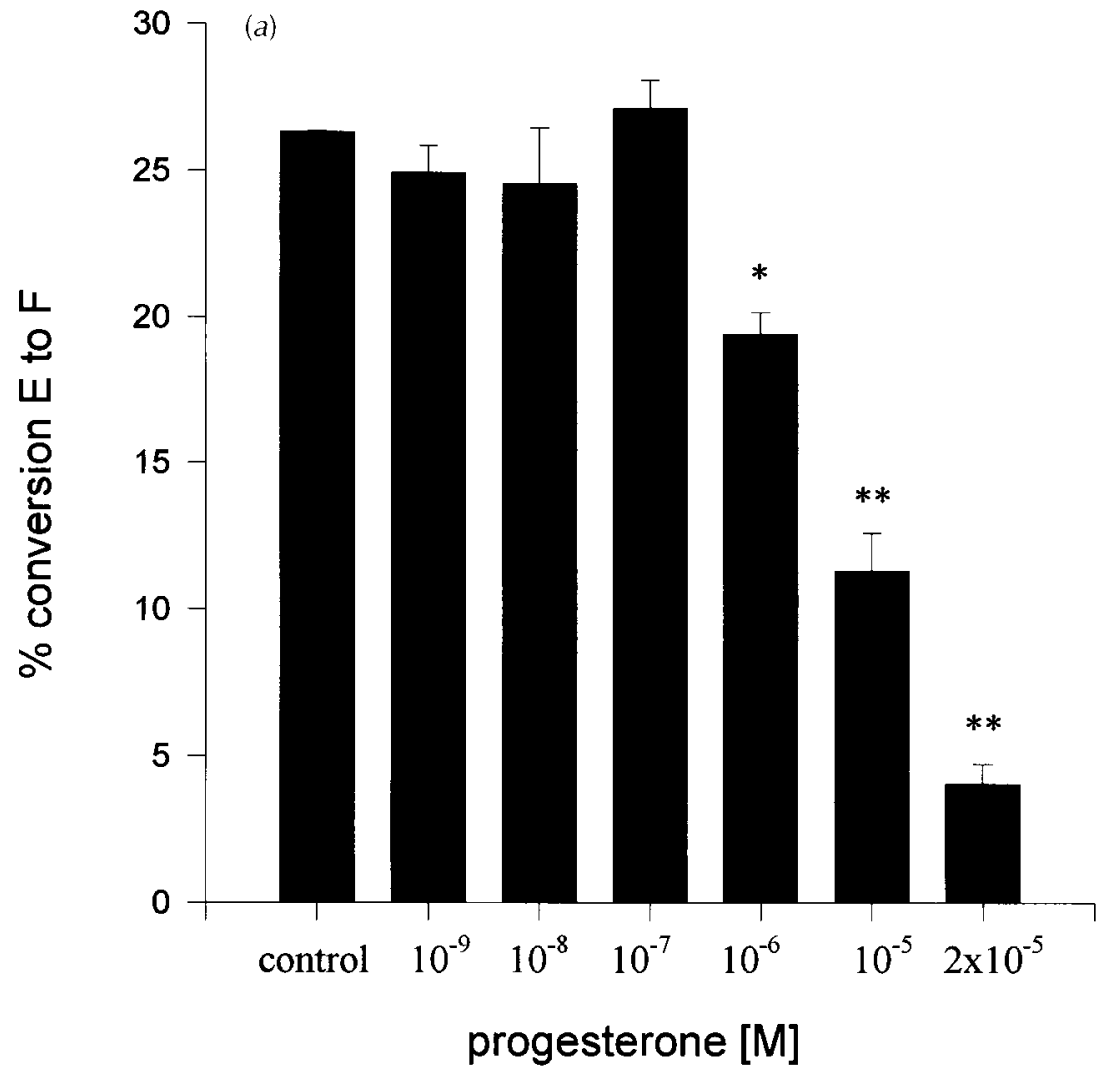

(b)

[Progesterone] M

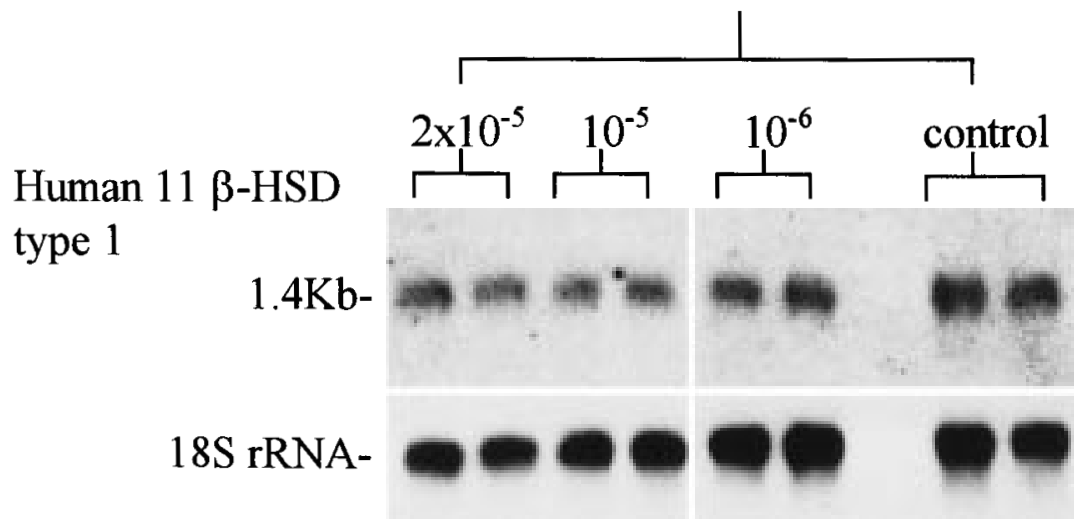

Figure 4 (a) Effects of $16 \mathrm{~h}$ pre-incubation with progesterone $\left(10^{-9}-2 \times 10^{-5} \mathrm{M}\right)$ on 11 oxo-reductase activity in human hepatocytes. Results are means \pm S.E., $n=3$ and are expressed as percentage conversion of $E$ to $F$ (cortisone to cortisol). ${ }^{*} P<0 \cdot 05,{ }^{*} P<0 \cdot 01$ compared with controls. (b) Northern blot showing the expression of type $111 \beta$-hydroxysteroid dehydrogenase mRNA in cultured human hepatocytes treated for $16 \mathrm{~h}$ with various doses of progesterone $\left(10^{-6}-2 \times 10^{-5} \mathrm{M}\right)$. Hybridization to $18 \mathrm{~S}$ rRNA is also shown as a control.

could also speculate that the discrepant activity/mRNA data reflects the presence of another 11 $\beta-H S D$ isozyme, an isozyme which acts in vivo as a pure reductase. In keeping with this suggestion, several patients have been described with a 'polycystic ovary syndrome'-like phenotype, who show a defect in the conversion of cortisone to cortisol (Phillipou \& Higgins 1985) but who do not have a mutation in the 11ß-HSD1 gene (Nikkila et al. 1993).

We conclude that the hepatic isozyme of $11 \beta-H S D$ is not regulated by EGF, bFGF, HGF or TGF $\beta_{1}$. CBX 
Table 3 Effects of carbenoxolone $\left(10^{-4}-10^{-7} \mathrm{M}\right)$ on 11 oxo-reductase activity in rat hepatocytes after 4 and $16 \mathrm{~h}$ pre-treatment. Results are means \pm S.E. $(n=3)$ and are expressed as percentage conversion of $\mathrm{A}$ to $\mathrm{B}$ (11-dehydrocorticosterone to corticosterone) relative to control. Also shown is the effect of carbenoxolone $\left(10^{-5}-10^{-8} \mathrm{M}\right)$ on 11 -oxo-reductase activity in human hepatocytes when incubated with $1 \mu \mathrm{M} \mathrm{E}$ (cortisone) for $4 \mathrm{~h}$. Results are means \pm S.E. $(n=3)$ and are expressed as percentage conversion of $\mathrm{E}$ to $\mathrm{F}$ (cortisone to cortisol) relative to control

\section{Percentage conversion A to B}

\begin{tabular}{lc}
\hline $4 \mathrm{~h}$ & \\
\cline { 1 - 1 } & \\
$100 \cdot 00 \pm 6 \cdot 99$ & $100 \cdot 00 \pm 2 \cdot 20$ \\
$26 \cdot 65 \pm 14 \cdot 01^{* *}$ & $22 \cdot 61 \pm 4 \cdot 09^{* *}$ \\
$61 \cdot 40 \pm 14 \cdot 19^{*}$ & $84 \cdot 33 \pm 5 \cdot 58$ \\
$106 \cdot 30 \pm 9 \cdot 57$ & $104 \cdot 70 \pm 1 \cdot 83$ \\
$121 \cdot 37 \pm 0 \cdot 12$ & $105 \cdot 13 \pm 0 \cdot 41$
\end{tabular}

Percentage conversion $\mathbf{E}$ to $\mathbf{F}(4 \mathrm{~h})$

\begin{tabular}{cc} 
Human & \\
\cline { 2 - 2 } Control & $100 \cdot 00 \pm 1 \cdot 06$ \\
$10^{-5}$ & $65 \cdot 03 \pm 1 \cdot 87^{* *}$ \\
$10^{-6}$ & $84 \cdot 72 \pm 3 \cdot 46^{*}$ \\
$10^{-7}$ & $99 \cdot 34 \pm 4 \cdot 63$ \\
$10^{-8}$ & $97 \cdot 05 \pm 0 \cdot 28$
\end{tabular}

${ }^{*} P<0 \cdot 05,{ }^{* *} P<0 \cdot 01$ compared with control.

inhibits 11 oxo-reductase activity within both rat and human hepatocytes. $\mathrm{T}_{3}$ increases 11 oxo-reductase activity in rat hepatocytes but not in human hepatocytes. The reverse is true for progesterone, i.e. no effect is seen in rat hepatocytes but activity is significantly inhibited in human hepatocytes. Our studies suggest that these effects are not mediated at a pre-translational level. There is a marked discrepancy between 11 oxo-reductase activity and $11 \beta$ HSD1 mRNA expression in cultured hepatocytes versus whole liver, and whilst this may reflect another isozyme of $11 \beta-H S D$, this requires further investigation. These results suggest that there is clear species-specific regulation of this isozyme of $11 \beta$-HSD in hepatocytes.

\section{Acknowledgements}

The authors would like to thank Mr Adrian Koegh for help with human hepatocyte preparations, Miss Kaljit Bratch for assistance in rat hepatocyte preparations, and Mrs Malgorzata Wilczynska for assistance in typing the manuscript.

\section{References}

Agarwal AK, Monder C, Eckstein B \& White PC 1989 Cloning and expression of rat cDNA encoding corticosteroid $11 \beta$-dehydrogenase. Journal of Biological Chemistry 264 18939-18943.
Albiston AL, Obeyesekene VR, Smith RE \& Krozowski ZS 1994 Cloning and tissue distribution of the human 11 $\beta$-hydroxysteroid dehydrogenase type 2 enzyme. Molecular and Cellular Endocrinology 105 R11-R17.

Bissell DM \& Guzelian PS 1980 Phenotypic stability of adult rat hepatocytes in primary monolayer cultures. Annals of the New York Academy of Sciences 349 128-137.

Braun L, Mead JE, Panzica M, Mikumio R, Bell GI \& Fausto N 1988 Transforming growth factor beta mRNA increases during liver regeneration: a possible paracrine mechanism of growth regulation. Proceedings of the National Academy of Sciences of the USA 85 1539-1543.

Brown RW, Chapman KE, Edwards CRW \& Seckl JR 1993 Human placental 11ß-hydroxysteroid dehydrogenase: partial purification of and evidence for a distinct NAD-dependent isoform. Endocrinology 132 2614-2621.

Bujalska IJ, Shimojo M, Howie A \& Stewart PM 1997 Human $11 \beta$-hydroxysteroid dehydrogenase: studies on the stably transfected isoforms and localization of the type 2 isozyme within renal tissue. Steroids 62 77-82.

Casey ML, MacDonald PC \& Andersson S 1994 17ß-Hydroxysteroid dehydrogenase type 2 : chromosomal assignment and progestin regulation of gene expression in human endometrium. Journal of Clinical Investigation 94 2135-2141.

Chan YL, Guttell R, Noller HF \& Wool I 1984 The nucleotide sequence of a rat $18 \mathrm{~S}$ ribosomal ribonucleic acid. Journal of Biological Chemistry 259 224-230.

Chomczynski P \& Sacchi N 1987 Single step method of RNA isolation by acid guanidinium thiocyanate-phenol-chloroform extraction. Analytical Biochemistry 162 156-159.

Clarke RJ, Thaventhiran L, Michael AE, Antoniw JW \& Cooke BA 1995 A possible physiological significance of the inhibition of $11 \beta$-hydroxysteroid dehydrogenase by progesterone and other ovarian steroids in human granulosa-lutein cells. Journal of Endocrinology 147 (Suppl) P95.

Edwards CRW, Stewart PM, Burt D, Brett L, McIntyre MA, Sutanto WS, deKloet R \& Monder C 1988 Localisation of $11 \beta$-hydroxysteroid dehydrogenase-tissue specific protector of the mineralocorticoid receptor. Lancet ii 986-989.

Hellman L, Bradlow HL, Zumoff B \& Gallagher TF 1961 The influence of thyroid hormone on hydrocortisone production and metabolism. Journal of Clinical Endocrinology and Metabolism 21 1231-1247.

Ismail T, Howl J, Wheatley M, McMaster P, Neuberger JM \& Strain AJ 1991 Growth of normal human hepatocytes in primary culture effect of hormones and growth factors on DNA synthesis. Hepatology 14 1076-1082.

Jamieson PM, Chapman KE, Edwards CRW \& Seckl JR 1995 $11 \beta$-Hydroxysteroid dehydrogenase is an exclusive $11 \beta$-reductase in primary cultures of rat hepatocytes: effect of physicochemical and hormonal manipulations. Endocrinology 136 4754-4761.

Koerner DR \& Hellman L 1964 Effect of thyroxine administration on the $11 \beta$-hydroxysteroid dehydrogenases in rat liver and kidney. Endocrinology 75 592-601.

Krozowski ZS 1992 11ß-Hydroxysteroid dehydrogenase and the short chain alcohol dehydrogenase superfamily. Molecular and Cellular Endocrinology 84 C25-C31.

Lakshmi V \& Monder C 1988 Purification and characterisation of the corticosteroid $11 \beta$-dehydrogenase component of the rat liver $11 \beta$-hydroxysteroid dehydrogenase complex. Endocrinology 123 2390-2398.

Low SC, Assaad SN, Rajan V, Chapman KE, Edwards CRW \& Seckl JR 1993 Regulation of $11 \beta$-hydroxysteroid dehydrogenase by sex steroids in vivo: further evidence for the existence of a second dehydrogenase in rat kidney. Journal of Endocrinology 139 27-35.

Monder C \& Shackleton CHL 1984 11ß-Hydroxysteroid dehydrogenase: fact or fancy? Steroids 44 383-417. 
Monder C, Stewart PM, Lakshmi V, Valentino R, Burt D \& Edwards CRW 1989 Licorice inhibits corticosteroid 11ß-dehydrogenase of rat kidney and liver: in vivo and in vitro studies. Endocrinology 125 1046-1053.

Monder C, Miroff Y, Marandici A \& Hardy M 1994 $11 \beta$-Hydroxysteroid dehydrogenase alleviates glucocorticoidmediated inhibition of steroidogenesis in rat Leydig cells. Endocrinology 134 1199-1204.

Mune T, Rogerson FM, Nikkila H, Agarwal AK \& White PC 1995 Human hypertension caused by mutations in the kidney isozyme of 113-hydroxysteroid dehydrogenase. Nature Genetics 10 394-399.

Nikkila H, Tannin GM, New MI, Taylor NF, Kalaitzoglou G, Monder C \& White PC 1993 Defects in the HSD11 gene encoding 11 1 -hydroxysteroid dehydrogenase are not found in patients with apparent mineralocorticoid excess or 11-oxoreductase deficiency. Journal of Clinical Endocrinology and Metabolism 77 687-691.

Pasquarette MM, Stewart PM, Ricketts ML, Imaishi K \& Mason JI 1996 Regulation of $11 \beta$-hydroxysteroid dehydrogenase type 2 activity and mRNA in human choriocarcinoma cells. Journal of Molecular Endocrinology 16 269-275.

Phillipou G \& Higgins BA 1985 A new defect in the peripheral conversion of cortisone to cortisol. Journal of Steroid Biochemistry 22 435-436.

Poutanen M, Isomaa V, Peltoketo H \& Vikho R 1995 Role of $17 \beta$-hydroxysteroid dehydrogenase type 1 in endocrine and intracrine estradiol biosynthesis. Journal of Steroid Biochemistry and Molecular Biology 55 525-532.

Rajan V, Edwards CRW \& Seckl JR 1996 11ß-Hydroxysteroid dehydrogenase in cultured hippocampal cells reactivates inert 11-dehydrocorticosterone, potentiating neurotoxicity. Journal of Neuroscience 16 65-70.

Rodin A, Thakkar H, Taylor N \& Clayton R 1994 Hyperandrogenism of polycystic ovary syndrome: evidence of dysregulation of $11 \beta$-hydroxysteroid dehydrogenase. New England Journal of Medicine 330 460-465.

Seglen PO 1976 Preparation of isolated rat liver cells. In Methods in Cell Biology, vol 13, pp 29-83. Ed DM Prescott. New York: Academic Press.

Shimojo M, Whorwood CB \& Stewart PM 1996 11ß-Hydroxysteroid dehydrogenase in the rat adrenal. Journal of Molecular Endocrinology 17 121-130.

Stewart PM, Wallace AM, Atherden SM, Shearing CH \& Edwards CRW 1990 Mineralocorticoid activity of carbenoxolone: contrasting effects of carbenoxolone and liquorice activity in man. Clinical Science 78 49-54.

Stewart PM, Burra P, Shackleton CHL, Sheppard MC \& Elias E 1993 $11 \beta$-Hydroxysteroid dehydrogenase deficiency and glucocorticoid status in patients with alcoholic and non-alcoholic chronic liver disease. Journal of Clinical Endocrinology and Metabolism 76 748-751.

Stewart PM, Murry BA \& Mason JI 1994 Human kidney $11 \beta$-hydroxysteroid dehydrogenase is a high affinity NAD-dependent enzyme and differs from the cloned type 1 isoform. Journal of Clinical Endocrinology and Metabolism 79 480-484.
Stewart PM, Krozowski ZS, Gupta A, Milford DV, Howie AJ, Sheppard MC \& Whorwood CB 1996 Hypertension in the syndrome of apparent mineralocorticoid excess due to mutation of the $11 \beta$-hydroxysteroid dehydrogenase type 2 gene. Lancet 347 $88-91$.

Strain AJ, Ismail T, Tsubouchi H, Hishida T, Kitamura N, Uhara Y \& McMaster P 1991 Native and recombinant human hepatocyte growth factor are highly potent promotors of DNA synthesis in both human and rat hepatocyte. Journal of Clinical Investigation $\mathbf{8 7}$ 1853-1857.

Tannin GM, Agarwal AK, Monder C, New MI \& White PC 1991 The human gene for 11 $\beta$-hydroxysteroid dehydrogenase. Journal of Biological Chemistry 266 16653-16658.

Tremblay Y \& Beaudoin C 1993 Regulation of 3 $\beta$-hydroxysteroid dehydrogenase and $17 \beta$-hydroxysteroid dehydrogenase messenger ribonucleic acid levels by cyclic AMP and phorbol myristate acetate in human choriocarcinoma cells. Molecular Endocrinology 7 355-364.

Walker BR, Campbell JC, Fraser R, Stewart PM \& Edwards CRW 1992 Mineralocorticoid excess and inhibition of $11 \beta$-hydroxysteroid dehydrogenase in patients with ectopic ACTH syndrome. Clinical Endocrinology 37 483-492.

Walker BR, Connacher AA, Lindsay RM, Webb DJ \& Edwards CRW 1995 Carbenoxolone increases hepatic insulin sensitivity in man: a novel role for 11-oxosteroid reductase in enhancing glucocorticoid receptor activation. Journal of Clinical Endocrinology and Metabolism 80 3155-3159.

Whorwood CB, Sheppard MC \& Stewart PM 1993a Licorice inhibits $11 \beta$-hydroxysteroid dehydrogenase messenger RNA levels and potentiates glucocorticoid hormone action. Endocrinology 132 2287-2292.

Whorwood CB, Sheppard MC \& Stewart PM $1993 b$ Tissue specific effects of thyroid hormone on $11 \beta$-hydroxysteroid dehydrogenase gene expression. Journal of Steroid Biochemistry and Molecular Biology 46 539-547.

Whorwood CB, Mason JI, Ricketts ML, Howie AJ \& Stewart PM 1995 Detection of human 11ß-hydroxysteroid dehydrogenase isoforms using reverse-transcriptase-polymerase chain reaction and localization of the type 2 isoform to renal collecting ducts. Molecular and Cellular Endocrinology 110 R7-R12.

Wilson RC, Krozowski ZS, Li K, Obeyesekere VR, Razzaghy-Azar M, Harbison MD, Wei JQ, Shackleton CHL, Funder JW \& New MI 1995 A mutation in the HSD11B2 gene in a family with apparent mineralocorticoid excess. Journal of Clinical Endocrinology and Metabolism 80 2263-2266.

Zhou MY, Gomez-Sanchez EP, Cox DL, Cosby D \& GomezSanchez CE 1995 Cloning, expression and tissue distribution of the rat nicotinamide adenine dinucleotide-dependent $11 \beta$ hydroxysteroid dehydrogenase. Endocrinology 136 3729-3734.

Zumoff B, Bradlow HL, Levin J \& Fukushima DK 1983 Influence of thyroid hormone on the in vivo cortisol-cortisone equilibrium in man. Journal of Steroid Biochemistry 18 437-440.

Received 18 February 1997

Revised manuscript received 10 June 1997

Accepted 3 September 1997 